\title{
Methods evaluated to minimize emissions from preplant soil fumigation
}

\author{
by Suduan Gao, Bradley D. Hanson, Dong \\ Wang, Gregory T. Browne, Ruijun Qin, Husein \\ A. Ajwa and Scott R. Yates
}

\section{Many commodities depend on} preplant soil fumigation for pest control to achieve healthy crops and profitable yields. Under California regulations, minimizing emissions is essential to maintain the practical use of soil fumigants, and more stringent regulations are likely in the future. The phase-out of methyl bromide as a broad-spectrum soil fumigant has created formidable challenges. Most alternatives registered today are regulated as volatile organic compounds because of their toxicity and mobile nature. We review research on methods for minimizing emissions from soil fumigation, including the effectiveness of their emission reductions, impacts on pest control and cost. Low-permeability plastic mulches are highly effective but are generally affordable only in high-value cash crops such as strawberry. Crops with low profit margins such as stonefruit orchards may require lower-cost methods such as water treatment or target-area fumigation.

Soil fumigation with methyl bromide Shas been used for decades in California to control a variety of soil-borne agricultural pests, such as nematodes, diseases and weeds. Major, high-value cash crops that rely on soil fumigation include strawberries; some vegetables such as carrot, pepper and tomato; and nurseries and orchards for stone fruit, ornamentals and grapevines. In California, tree and grapevine field nurseries must meet requirements of the California Department of Food and Agriculture (CDFA) Nursery Nematode

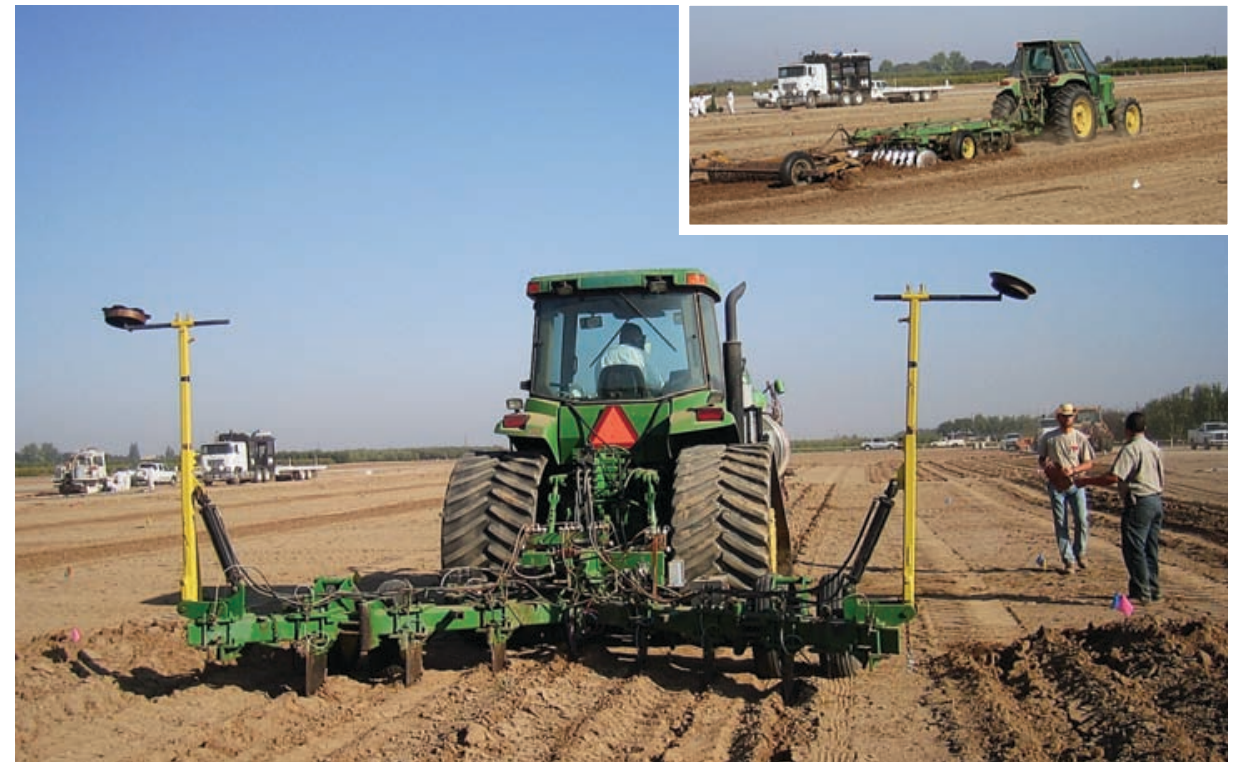

Shank application of 1,3-D is followed by a disking/rolling operation, inset, to break the shank trace and compacted soil surface.

Control Program (CDFA 2008). Without fumigants, the productivity of these cropping systems would suffer from yield losses due to diseases, replant disorders or lack of phytosanitary certification.

Because of its role in depleting stratospheric ozone, methyl bromide was phased out in the United States and other developed countries as of January 2005, under provisions of the U.S. Clean Air Act and the Montreal Protocol (an international agreement). Some limited uses of methyl bromide are permitted under critical-use exemptions and quarantine/preshipment criteria, which are subject to application and approval annually.

Limited to a few registered compounds, growers have turned to alternative fumigants such as 1,3dichloropropene (Telone or 1,3-D), chloropicrin $(\mathrm{CP})$ and methyl isothiocyanate (MITC) generators (metam sodium or dazomet) (Trout 2006). In addition to direct toxicity, most of these alternative fumigants are also regulated as volatile organic compounds (VOCs). Some VOCs released into the atmosphere can react with nitrogen oxides under sunlight to form harmful ground-level ozone, an important air pollutant.
Regulations such as use limits and buffer zones have been used to minimize emissions and protect public and environmental health. More-stringent regulations are being developed for fumigants to reduce air emissions, especially in ozone-nonattainment areas such as Ventura County and the San Joaquin Valley (CDPR 2008; Segawa 2008).

The UC Statewide Integrated Pest Management Program recently prepared a field fumigation guide for emission control, which is available on the California Department of Pesticide Regulation website (UC IPM 2009). This paper is not intended to represent or serve as a replacement for that guide, but rather to update findings on emission-reduction technologies, including projects under the U.S. Research Service (USDA-ARS) Pacific Area-Wide Pest Management Program. We summarize extensive research on emission reduction from soil fumigation conducted over the last few years, and identify agricultural practices for minimizing fumigant emissions while achieving good efficacy. We also identify knowledge gaps and other research needs for the near future. Department of Agriculture Agricultural 


\section{Factors affecting emissions}

Soil fumigants are volatile chemical compounds. The purpose of fumigation is to achieve maximum control of soilborne pests, which requires an effective concentration or exposure duration and the uniform distribution of fumigants in soil. A number of processes affect the fate of fumigants after soil application (fig. 1). Fumigants are subject to partitioning into soil air, water and solid phases (most importantly, organic matter); volatilization (emission); degradation (chemical and microbial), movement in soil via diffusion; and potential leaching. Volatilization and leaching can potentially contaminate the air and water. Emission loss is a major airquality concern. To minimize emissions as well as ensure efficacy, it is necessary

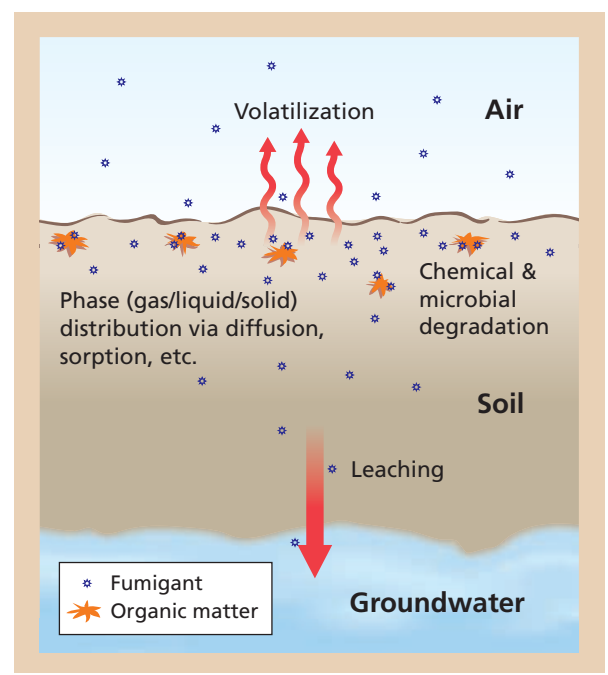

Fig. 1. Processes affecting the fate of fumigants in soil.

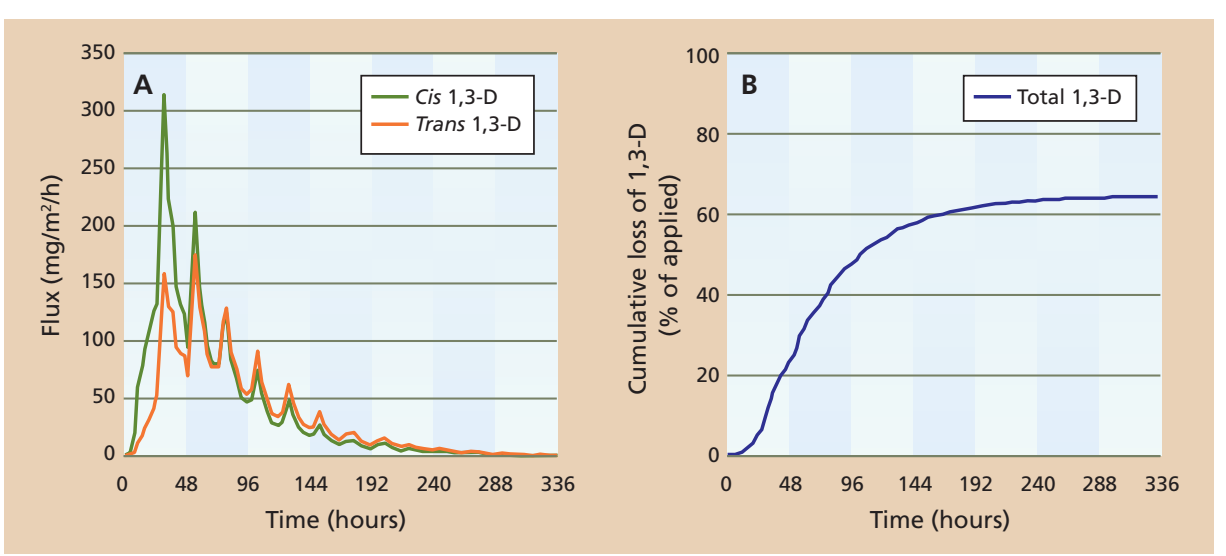

Fig. 2. Emission flux from a bare surface soil after shank injection of 1,3-dichloropropene (1,3-D) (with $2.5 \%$ inert ingredients) at an 18-inch depth into a sandy loam soil. The 1,3-D included cisand trans-isomers; the sum of the isomers volatilized over time divided by the total applied gives the cumulative emission loss.

to contain fumigants in the rhizosphere where plant roots are present and soilborne pests are dominant. Without proper containment, more than half of fumigants applied can be lost through emissions (fig. 2).

Fumigant lost into the atmosphere not only contributes to air pollution, but also translates into

wasted resources

intended for soil pest control.

Soil conditions (such as texture, moisture and organic matter content), weather and surface barriers, and the chemical properties of the fumigant can all affect emissions. Generally speaking, lower emissions are expected from soils with fine texture, high water content, high organic-matter content and low temperature compared to dry soils with coarse texture, low organic-matter content and high temperature. Approaches to reducing fumigant emissions include application methods such as equipment design (injection depth), physical barriers, irrigation, soil amendment with chemicals or organic materials and target-area treatment.

Current application techniques include broadcast fumigation and chemigation. With standard broadcast fumigation, fumigants are applied directly to the soil at a certain depth using conventional equipment or rigs (shanks). Chemigation is injecting fumigants into soil with irrigation water through sprinklers or drip tapes.

\section{Fumigant lost to atmospheric emissions not only contributes to air pollution, but also translates into wasted resources intended for soil pest control.}

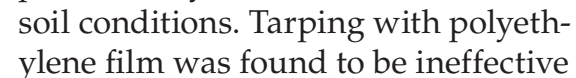

inches (30 to 60 centimeters) resulted in a $20 \%$ or greater reduction of methyl bromide emissions in bare soils (Yates et al. 2002).

The general consensus for bare-soil fumigation is that emissions from drip application, especially subsurface, are lower than broadcast-shank injections (Gao, Trout, Schneider 2008; Wang et al. 2009). This is attributable to two factors: (1) increasing soil water content decreases air pore volume (i.e., vapor diffusion) and increases the amount of fumigant partitioning in the aqueous phase and (2) there are no shank traces (i.e., soil fractures) that can serve as volatilization channels. The fumigant diffusion rate in the liquid phase is much slower than in the gas phase. Substantially higher soil water content would reduce the fumigant's distribution in soils by reducing vapor diffusion, reducing efficacy. Good efficacy can only be ensured when the fumigant moves with applied water for a relatively uniform distribution (Ajwa and Trout 2004). However, because fumigants are highly volatile, drip-applied fumigants near soil surfaces without any barriers may still result in high emission losses. Currently, about half of California's strawberry acreage, especially in the coastal areas, is fumigated using drip application.

\section{Plastic films}

Plastic tarping or "mulching" is the most commonly used practice to contain fumigants in soil and control emissions. The effectiveness of tarping on emission reduction depends largely on the chemical's characteristics and tarp ermeability, and also to some extent on lene film was found to be ineffective 


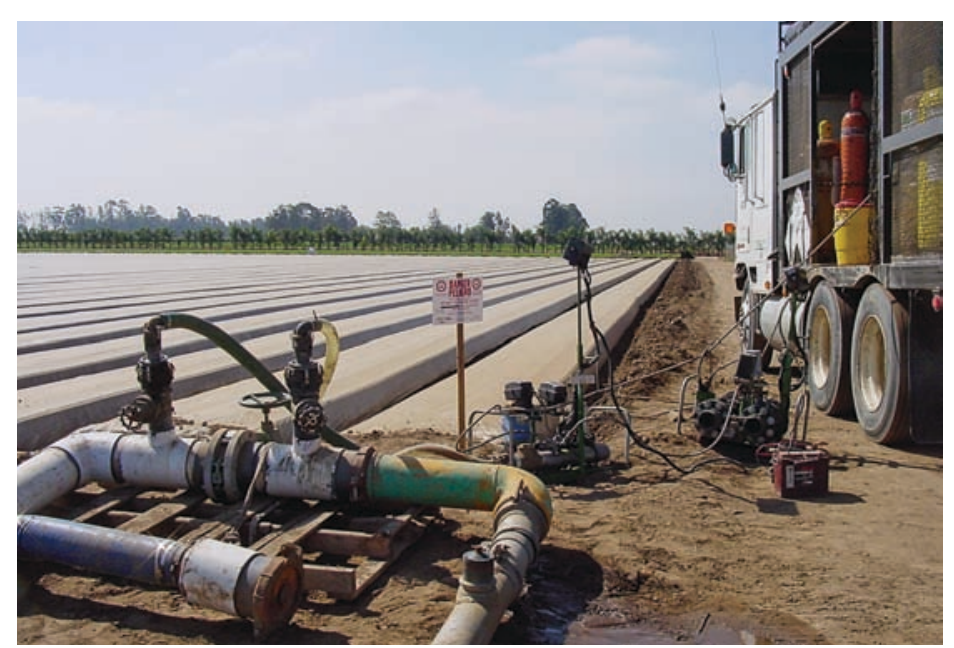

A company applies fumigant through drip irrigation in a strawberry field.

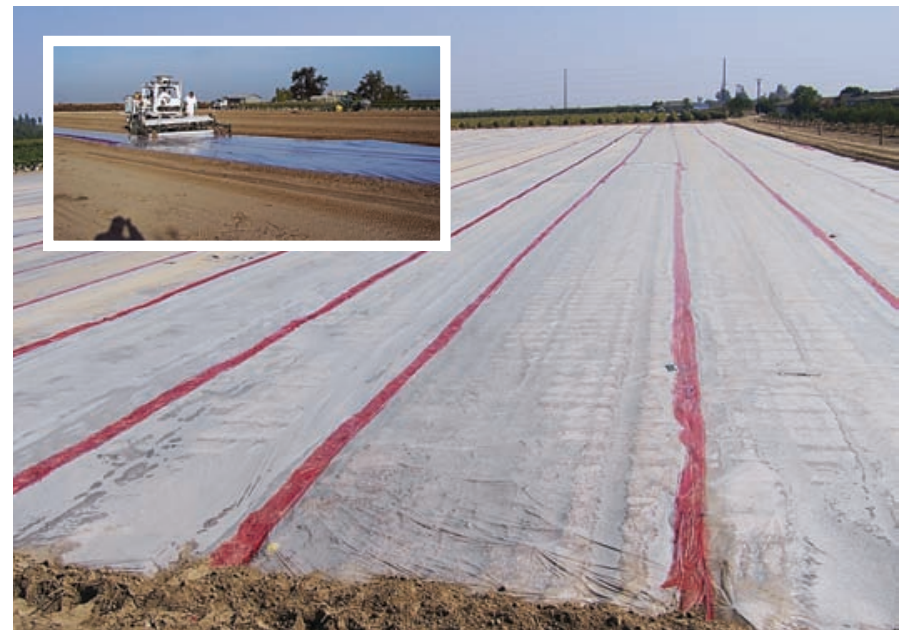

Plastic tarping minimizes emissions following fumigant application. to control 1,3-D emissions, especially in relatively dry soils (Gao and Trout 2007; Papiernik and Yates 2002). However, high-density polyethylene (HDPE) tarp applied over irrigated soil can substantially lower 1,3-D emissions, due to both higher soil water content and water condensation under the film (Gao and Trout 2007). About 50\% emission reduction was measured for an HDPEtarped treatment in relatively cooler fall weather conditions, compared to bare soil (Gao, Hanson, et al. 2009). Tarped treatment in pre-irrigated soil in summer may also improve pest control due to elevated soil temperatures under the tarp. Shrestha et al. (2006) observed significant reductions in weed populations due to high temperatures up to $117^{\circ} \mathrm{F}$ under the tarp, which was partially attributed to the effect of solarization.

Virtually impermeable film. Lowpermeability films, including virtually impermeable film (VIF), showed great potential in early laboratory or smallplot tests (Wang et al. 1997b). VIF has much lower permeability to most fumigants than HDPE films (Ajwa 2008).

VIF is generally a multilayered film composed of barrier polymers such as nylon or ethyl vinyl alcohol (EVOH) sandwiched between polyethylene polymer layers (Villahoz et al. 2008). A number of studies have shown that VIF can retain higher fumigant concentrations than HDPE film, reducing emissions while improving efficacy, especially for weed control (Hanson et al. 2008; Noling 2002). The effectiveness of VIF in large-field applications has been difficult to ascertain because it can be damaged during field installation, with potential changes in permeability.

Recent field data confirmed that this type of film can effectively reduce emissions more than 90\% (Ajwa 2008; Gao, Qin, et al. 2009). The tarp permeability did increase after field installation but was still substantially lower than that of polyethylene films (Qin, Gao, Ajwa 2008; Yates 2008). There are also concerns about damage from field installation and improper gluing materials in the VIF tarp. These potential problems, however, were not observed in a recent field trial (Gao, Hanson, et al. 2009), when a Bromostop VIF (0.025millimeter thickness) from Bruno Rimini Corp. (London, U.K.) was applied to a shank-injected 1,3-D (Telone II) field, achieving greater than $95 \%$ emission reduction.

Totally impermeable film. A new type of low-permeability film, so-called totally impermeable film (TIF), was reportedly easier to install and maintain in field applications (Chow 2008; Villahoz et al. 2008). This film has even lower permeability to fumigants than some other VIFs (Ajwa 2008). For example, the mass-transfer coefficient (indicating tarp permeability to fumigants) for TIF was 0.0004 inch (0.001 centimeter) per hour for cis 1,3-D compared to 0.028 inch (0.07 centimeter) per hour for Bromostop VIF before field application, and 0.008 inch ( 0.02 centimeter) versus 0.106 inch ( 0.27 centimeter) per hour, respectively, after installation over raised beds in the field.

TIF is a five-layer film incorporated with a middle layer of EVOH into a standard polyethylene-based film (Chow 2008). Information on field emission reductions is insufficient because this film has not been made available commercially. The most recently reported research data indicated that TIF can have similar effectiveness in reducing emissions as other VIFs; but these low-permeability films can cause emission surges when the tarp is cut and after about 1 week, due to the release of high amounts of retained fumigant (Gao et al. 2010). These emission surges would increase exposure risks to workers and bystanders. To reduce the risk, the waiting period between fumigation and tarp cutting or removal should be long enough for fumigants to degrade under the tarp. VIFs can retain fumigants under the tarp, making lower application rates possible, provided that satisfactory pest control can be achieved. The low-permeability films also showed the potential to improve the uniformity of fumigant distribution up to a certain depth in the soil profile, so lower application rates than are currently used for bare soil or underneath standard polyethylene film would be possible.

\section{Water seals and pre-irrigation}

With proper management, postfumigation water seals (with sprinklers) and pre-irrigation can reduce emissions to some extent. The latter is used to achieve adequate soil moisture if the soil is dry, but not to a level that would inhibit fumigant movement/distribution in the soil profile. Water seals reduce fumigant emissions by forming a 
TABLE 1. Emission-reduction potential and cost estimates for surface sealing/treatments to reduce emissions from soil fumigation

\begin{tabular}{|c|c|c|c|}
\hline Soil-surface treatment & Emission-reduction potential & Cost (excluding fumigant) & Other considerations \\
\hline Bare soil & $\begin{array}{l}\text { Reference level, often }>60 \% \text { of } \\
\text { total applied fumigant emissions }\end{array}$ & $\begin{array}{l}\text { Not estimated for field preparations such as disking } \\
\text { and compaction }\end{array}$ & \\
\hline HDPE tarp & $\begin{array}{l}\text { Up to } 50 \% \text {, depending on soil } \\
\text { moisture and temperature }\end{array}$ & $\begin{array}{l}\text { HDPE: } \$ 950-\$ 1,100 \text { per acre (materials, } \sim \$ 500 \text {; glue, } \\
\$ 100 \text {; application, } \$ 350 \text {; cutting and removal, } \$ 100 \text { ) }\end{array}$ & Effective in relatively moist soils \\
\hline Low-permeability tarps (e.g., VIF) & $\begin{array}{l}>90 \% \text {, if tarp is installed } \\
\text { successfully }\end{array}$ & $\begin{array}{l}\text { VIF: } \$ 1,200-\$ 1,600 \text { per acre, assuming material cost } \\
\text { is } 1.5 \text { to } 2 \text { times HDPE, and other costs similar to } \\
\text { HDPE }\end{array}$ & $\begin{array}{l}\text { Effective in almost all conditions; } \\
\text { unclear time needed for safe tarp } \\
\text { removal }\end{array}$ \\
\hline Water treatment & $\begin{array}{l}20 \%-50 \% \text {, depending on } \\
\text { water amount and number of } \\
\text { applications }\end{array}$ & $\begin{array}{l}<\$ 300 \text { per acre, depending on water price and } \\
\text { whether grower owns or rents sprinkler system }\end{array}$ & $\begin{array}{l}\text { May reduce efficacy at surface soil, } \\
\text { requiring double treatments in } \\
\text { sequence }\end{array}$ \\
\hline Chemicals (e.g., thiosulfate) & $>50 \%$ & $\begin{array}{l}\text { Fumigant-to-thiosulfate active ingredient ratio of } \\
1: 1 \text { to } 1: 2 \text {, at } \$ 150-\$ 300 \text { per acre }\end{array}$ & $\begin{array}{l}\text { Oversupply of nutrients to soil, } \\
\text { post-treatment odor and potential } \\
\text { soil-property changes }\end{array}$ \\
\hline Composted manure & Inconclusive & $\begin{array}{l}\text { Depends on application rate and material costs; } \\
\text { commercial composted manure is } \$ 15-\$ 30 \text { per ton }\end{array}$ & $\begin{array}{l}\text { Improves soil properties; consider } \\
\text { when free or low-cost materials are } \\
\text { available }\end{array}$ \\
\hline
\end{tabular}

techniques for different commodities (table 1). Field data from a number of trials showed that low-permeability plastic tarps are the most promising technique but also the most costly. The commonly used standard polyethylene tarp costs about $\$ 950$ to $\$ 1,100$ per acre depending on acreage, with higher costs for small acreage and lower costs for large acreage (personal communication, industry representatives). Costly plastic materials may not be affordable for commodities with low profit margins, such as stone fruit orchards and annual vegetables.

Low-permeability films such as VIF or TIF generally cost 1.5 to 2 times the cost of polyethylene films. In addition to the higher cost for VIF, high levels of fumigants may be released into the atmosphere upon removal or when planting holes are cut into the tarp. To reduce potential exposure risks, longer waiting periods between fumigation and tarp cutting/removal are necessary to allow fumigant degradation in soils. This issue requires further detailed investigation, as the fate of fumigants would vary depending on the soil and environmental conditions. If applicable, the injection of thiosulfate through drip irrigation under the tarp may effectively reduce this risk (Qin et al. 2007), although no field tests have been done.

Caution must be taken when considering a chemical treatment such as thiosulfate for reducing emissions. The cost of this chemical fertilizer is low, at less than $\$ 2$ per gallon (about 11 pounds) of ammonium thiosulfate (Thio-Sul, containing $12 \%$ nitrogen and $26 \%$ sulfur). To meet crop sulfur requirements, ammonium thiosulfate is recommended at 6 to 12 gallons per acre for row and vegetable crops, and 5 to 10 gallons per acre for trees and vines using soil injection and surface banding, or 15 to 20 gallons per acre in a broadcast spray (www.tkinet.com/thiosul.html). However, fumigation rates are often much higher than fertilization rates. For example, 1,3-D can be applied at a maximum rate of 33.7 gallons (332 pounds active ingredient) per acre in California. Research showed that to significantly reduce emissions, thiosulfate and fumigant are needed at a ratio greater than one-to-one in molecular weight. For 1,3-D, a one-to-one ratio would require about 75 gallons of ammonium thiosulfate containing the active ingredient, at a cost of about $\$ 150$ per acre. While this level of thiosulfate would likely reduce emissions, it could also introduce excessive nutrients or salts that cause other serious crop-production concerns. Thus, large-field applications of chemical treatment with thiosulfate are undesirable. Additional concerns with chemical treatment are the post-application odor and potential soil-property changes that have not been fully addressed.

Water seals, deep injection, drip application and the incorporation of high rates of organic materials are also low-cost options to control fumigant emissions. Using water costs much less than plastic tarps and offers some environmental benefits, because no materials must be disposed of. The cost for a 25-millimeter water application by sprinklers ranges from $\$ 100$ to $\$ 300$ per acre, depending on whether the grower owns or rents the sprinkler system. The overall cost of using water is currently substantially lower than plastic tarps, but this may change over time depending on water supplies in California.

Commercially available, clean, composted manure costs $\$ 15$ to $\$ 30$ per ton. The costs to apply higher rates than 25 tons per acre may not be feasible for commodities with low profit margins. In some situations, composted green waste from municipalities may be available at no cost; however, this material may also contain other undesirable waste products, such as plastic.

\section{Research needs}

Reducing emissions from soil fumigation is required to comply with environmental regulations. Low emissions can be achieved through the management of application methods such as deep injection and subsurface drip, physical barriers with plastic films, irrigation to form water seals or achieve relatively moist soil conditions, and the reduction of treatment areas to planting rows or sites. Soil chemical treatment (e.g., thiosulfate) can be effective in lowering emissions and may prove to be an effective strategy for extreme cases, such as fumigant spills. Although the incorporation of composted dairy manure to surface soil at or 
below 25 tons per acre did not reduce emissions in some field tests, the longer incorporation times and higher rates accompanied by certain soil preparations or more effective materials may have the potential to reduce emissions and improve soil physiochemical properties. Low-permeability plastic tarps such as VIF have shown the most promise in reducing emissions while improving efficacy. This type of film may also need lower application rates, which can help compensate for its high cost.

Research on the performance of the next generation of low-permeability

\section{References}

Ajwa H. 2008. Testing film permeability to fumigants under laboratory and field conditions. In: Proc Ann Int Res Conf on MeBr Alternatives and Emission Reductions, Nov. 11-14, 2008. Orlando, FL. p 35(1-2).

Ajwa HA, Trout TJ. 2004. Drip application of alternative fumigants to methyl bromide for strawberry production. HortScience 39:1707-15.

Ashworth DJ, Yates SR. 2007. Surface irrigation reduces the emission of volatile 1,3-dichloropropene from agricultural soils. Env Sci Technol 41:2231-6.

Browne G. 2008. Integrated pre-plant alternatives to methyl bromide for almonds and other stone fruits. In: Proc Ann Int Res Conf on $\mathrm{MeBr}$ Alternatives and Emission Reductions, Nov. 11-14, 2008. Orlando, FL. p 12(1-4).

[CDFA] California Department of Food and Agriculture. 2008. Nematode Inspection Procedures Manua (NIPM). Sacramento, CA. www.cdfa.ca.gov/phpps/pe/ NIPM.htm.

[CDPR] California Department of Pesticide Regulation. 2008. Ventura County fumigation emission allowances from May 1 to October 31, 2008. Sacramento, CA. www.cdpr.ca.gov/docs/emon/vocs/vocproj/emission. htm.

Chow E. 2008. Properties of EVOH and TIF films for the reduction of fumigant dosage and VOC emission. In: Proc Ann Int Res Conf on MeBr Alternatives and Emission Reductions, Nov. 11-14, 2008. Orlando, FL. p 38(1).

Gan J, Becker JO, Ernst FF, et al. 2000. Surface application of ammonium thiosulfate fertilizer to reduce volatilization of 1,3-dichloropropene from soil. Pest Manag Sci 56:264-70.

Gan J, Yates SR, Becker JO, Wang D. 1998. Surface amendment of fertilizer ammonium thiosulfate to reduce methyl bromide emission from soil. Env Sci Technol 32:2438-41.

Gan J, Yates SR, Wang D, Ernst FF. 1998. Effect of application methods on 1,3-D volatilization from soil under controlled conditions. J Env Qual 27:432-8.

Gao S, Hanson B, Qin R, et al. 2009. Measurement and assessment of field emission reductions. In: Proc Ann Int Res Conf on MeBr Alternatives and Emission Reductions, Nov. 11-13, 2009. San Diego, CA. p 9(1-3).

Gao S, Qin R, Ajwa H, et al. 2010. Evaluation of TIF to reduce fumigant emissions and the potential to use reduced rates. Ann Int Res Conf on $\mathrm{MeBr}$ Alternatives and Emission Reductions, Orlando, Nov 2-5. p 12(1-4) Gao S, Qin R, Hanson BD, et al. 2009. Effects of manure and water applications on 1,3-dichloropropene and chloropicrin emission in a field trial. J Agr Food Chem 57:5428-34. films is needed for large-field applications. Any emission-reduction technology that enhances degradation or reduces fumigant concentration in soil or surface soil would have an undesirable impact on pest control because of the reduction in exposure dosage. This makes it more desirable to use low-permeability tarps, which unfortunately cost the most. Feasible techniques for different commodities depend on their availability to the production system, effectiveness in emission reduction, potential impact on pest control and cost.

Gao S, Qin R, McDonald JA, et al. 2008. Field tests of surface seals and soil treatments to reduce fumigant emissions from shank-injection of Telone C35. Sci Total Env 405:206-14.

Gao S, Trout TJ. 2007. Surface seals to reduce 1,3dichloropropene and chloropicrin emissions in field tests. J Env Qual 36:110-9.

Gao S, Trout TJ, Schneider S. 2008. Evaluation of fumigation and surface seal methods on fumigant emissions in an orchard replant field. J Env Qual 37:369-77.

Hanson BD, Gao S, Gerik J, et al. 2008. Pest control with California approved nursery stock certification 1,3-D treatments. In: Proc Ann Int Res Conf on MeBr Alternatives and Emission Reductions, Nov. 11-14, 2008. Orlando, FL. p 25(1-4).

Noling JW. 2002. Reducing methyl bromide field application rates with plastic mulch technology. Pub ENY-046, Institute of Food and Agricultural Sciences, University of Florida, Gainesville, FL.

Papiernik SK, Yates SR. 2002. Effect of environmental conditions on the permeability of high density polyethylene film to fumigant vapors. Env Sci Technol 36:1833-8.

Qin R, Gao S, Ajwa H. 2008. Low permeable tarps reduce emissions from drip-applied inline in a strawberry field trial. In: Proc Ann Int Res Conf on MeBr Alternatives and Emission Reductions, Nov. 11-14, 2008. Orlando, FL. p 114 (1-4).

Qin R, Gao S, Hanson BD, et al. 2007. Effect of drip application of ammonium thiosulfate on fumigant degradation in soil columns. J Agr Food Chem 55:8193-9.

Qin R, Gao S, McDonald JA, et al. 2008. Effect of plastic tarps over raised-beds and potassium thiosulfate in furrows on chloropicrin emissions from drip fumigated fields. Chemosphere 72:558-63.

Segawa R. 2008. California regulatory issues for fumigants. Presentation at Ann Int Res Conf on MeBr Alternatives and Emission Reductions, Nov. 11-14, 2008 Orlando, FL. www.mbao.org/2008/004segawa.pdf.

Shrestha A, Gao S, Trout TJ. 2006. Surface water applications for reducing emissions from Telone C35: Their effect on weed populations. In: Proc Ann Int Res Conf on $\mathrm{MeBr}$ Alternatives and Emission Reductions, Nov. 6-9, 2006. Orlando, FL. p 116(1-4).

Sullivan DA, Holdsworth MT, Hlinka DJ. 2004. Control of off-gassing rates of methyl isothiocyanate from the application of metam-sodium by chemigation and shank injection. Atmos Env 38:2457-70.

Trout T. 2006. Fumigant use in California - response to the phase-out. In: Proc Ann Int Res Conf on $\mathrm{MeBr}$ Alternatives and Emission Reductions, Nov. 6-9, 2006. Orlando, FL. p 18(1-6).
S. Gao is Research Soil Scientist, Water Management Research Unit, U.S. Department of Agriculture Agricultural Research Service (USDA-ARS), Parlier; B.D. Hanson is Cooperative Extension Specialist, Department of Plant Sciences, UC Davis; D. Wang is Research Leader, Water Management Research Unit, USDA-ARS, Parlier; G.T. Browne is Project Coordinator, USDA-ARS Pacific Area-Wide Pest Management Program, UC Davis; $R$. Qin is Postdoctoral Research Associate, and H.A. Ajwa is Cooperative Extension Specialist, Department of Plant Sciences, UC Davis; and S.R. Yates is Research Leader, Contaminant Fate and Transport Unit, USDA-ARS, Riverside.

[UC IPM] UC Statewide Integrated Pest Management Program. 2009. Field Fumigation. UC ANR Pub 9005. Oakland, CA. 121 p.

Villahoz MD, Garza F, Barrows P, Sanjurjo M. 2008. TIF (totally impermeable film): An innovative film for mulch, broadcast fumigation, and greenhouses in agriculture. In: Proc Ann Int Res Conf on MeBr Alternatives and Emission Reductions, Nov 11-14, 2008. Orlando, FL. p 37(1-2)

Wang D, Browne B, Gao S, et al. 2009. Spot fumigation: Fumigant gas dispersion and emission characteristics. Env Sci Technol 43:5783-9.

Wang D, Juzwik J, Fraedrich SW, et al. 2005. Atmospheric emissions of methyl isothiocyanate and chloropicrin following soil fumigation and surface containment treatment in bare-root forest nurseries. Can J Forest Res 35:1202-12.

Wang D, Yates SR, Ernst FF, et al. 1997a. Methyl bromide emission reduction with field management practices. Env Sci Technol 31:3017-22.

Wang D, Yates SR, Ernst FF, et al. 1997b. Reducing methyl bromide emission with a high barrier plastic film and reduced dosage. Env Sci Technol 31:3686-91.

Wang Q, Gan J, Papiernik SK, Yates SR. 2000 Transformation and detoxification of halogenated fumigants by ammonium thiosulfate. Env Sci Technol 34:3717-21.

Xu JM, Gan J, Papiernik SK, et al. 2003. Incorporation of fumigants into soil organic matter. Env Sci Technol 37:1288-91.

Yates SR. 2008. Update of film permeability measurements for USDA-ARS area-wide research project. In: Proc Ann Int Res Conf on MeBr Alternatives and Emission Reductions, Nov. 11-14, 2008. Orlando, FL. p 18(1-4).

Yates SR, Gan J, Papiernik SK, et al. 2002. Reducing fumigant emissions after soil application. Phytopathology 92:1344-8.

Yates SR, Knuteson J, Ernst FF, et al. 2008a. Reducing field-scale emissions of 1,3-D with composted munici pal green-waste. In: Proc Ann Int Res Conf on MeBr Alternatives and Emission Reductions, Nov. 11-14, 2008. Orlando, FL. p 32(1-3).

Yates SR, Knuteson J, Ernst FF, et al. 2008b. The effect of sequential surface irrigations on field-scale emissions of 1,3-dichloropropene. Env Sci Technol 42:8753-8.

Zheng W, Gan J, Papiernik SK, Yates SR. 2007. Identification of volatile/semivolatile products derived from chemical remediation of cis-1,3-dichloropropene by thiosulfate. Env Sci Technol 41:6454-9. 